\title{
Hereditary folate malabsorption
}

INSERM

\section{Source}

INSERM. (1999). Orphanet: an online rare disease and orphan drug data base. Hereditary folate malabsorption. ORPHA:90045

Hereditary folate malabsorption (HFM) is an inherited disorder of folate transport characterized by a systemic and central nervous system (CNS) folate deficiency manifesting as megaloblastic anemia, failure to thrive, diarrhea and/or oral mucositis, immunologic dysfunction and neurological disorders. 